\title{
Description of Aedes aegypti Larva Density Based on Mosquito Breeding Eradication Action in the Dengue Endemic Rappocini Sub-District Makassar
}

\author{
Hasanuddin Ishak ${ }^{1}$, Novita Toding ${ }^{2}$, Muh.Fajaruddin Natsir ${ }^{3}$, Hasnawati Amqam ${ }^{4}$ \\ \{hasanuddin.ishak@unhas.ac.id ${ }^{1}$, novitahwangminhyun25@gmail.com² ${ }^{2}$ ahmadfajarislam@unhas.ac.id ${ }^{3}$, \\ hasnawati.amqam@unhas.ac.id $\left.{ }^{4}\right\}$
}

Universitas Hasanuddin Kampus Tamalanrea, Jl. Perintis Kemerdekaan KM.10 Makassar ${ }^{1-4}$

\begin{abstract}
Dengue Haemorrhagic Fever (DHF) is a disease that can be transmitted from a sick person to a healthy person through a mosquito bite (vector) Aedes aegypti or Aedes albopictus. Disease caused by the dengue virus is an infectious disease which causes disruption in capillary blood vessels and in the blood clotting system. DHF transmission can be prevented by breaking the chain of transmission by means of vector control through the activities of Mosquito Breeding Eradication (PSN). The aim of this study was to determine the density of Aedes aegypti larvae based on PSN actions in endemic areas in Makassar city. The research was an observational survey with a descriptive approach using questionnaires and through direct observation using observation sheets. The population was all houses in RW 05, RW 06 and RW 08 Gunung Sari village as DHF endemic areas. Determination of the sample was carried out by purposive random sampling method that obtained of 126 houses. The coordinate points of houses were poured on the map using Arc GIS 10.3. The results of this study indicate that the density of Aedes aegypti larvae in DHF endemic areas was low as measured using larva-free rate (ABJ) which was 37.3\%, House Index (HI) 62,7\%, and Container Index (CI) 32,4\%. The PSN actions carried out in the majority DHF endemic areas was $65.9 \%$ which was categorized as good. The role of jumantik (Larva monitors) in controlling DHF in endemic areas of DHF has not been implemented optimally.
\end{abstract}

Keywords: Attitude

\section{Introduction}

Dengue Hemorrhagic Fever (DHF) is a disease that can be transmitted from sick people to healthy people through infectious mosquito bites (vectors) [4], namely Aedes aegypti or Aedes albopictus. Aedes aegypti mosquito is the main vector that causes this disease carrying the dengue virus after sucking the blood of people who have been infected with the virus. The first epidemic of dengue fever was reported from 1779 to 1780 in Asia, Africa, and North America. Then, around in 1975-1995, DHF was detected in 102 countries from five WHO regions [1], namely 20 countries in Africa, 42 countries in America, 7 countries in Southeast Asia, 4 countries in the Eastern Mediterranean, and 29 countries in the Western Pacific [5]. 1.6 billion $(52 \%)$ of the population in Southeast Asia are infected by the dengue virus. Meanwhile the 
World Health Organization (WHO) records Indonesia as the country in Southeast Asia that has the highest DHF cases.

DHF in Indonesia has spread to all regions with the number of districts/cities affected, increasing to inland areas. In 2017, from January to May, there were 17,877 cases and among them 115 deaths.5 According to the report on the Division of Disease Control and Environmental Health (P2PL), the number of dengue cases that occurred in South Sulawesi in 2013 with the number of cases found as many 5,030 cases. Makassar City is one of the cities in South Sulawesi Province that is endemic for dengue fever which has fluctuations in the number of dengue sufferers. The highest number of dengue fever in the last 5 years occurred in 2013, which showed 265 patients per 100,000 population. In 2017 there were 127 cases from January to October of the year and caused 1 patient to die [3].

DHF cases in Rappocini Subdistrict are one of fourteen cases in Makassar City with a high number of DHF cases but have fluctuations in the last 4 years. In 2014 there were 44 cases, 2015 as many as 19 cases, and in 2016 as many as 35 cases. According to the latest data from the Makassar City Health Office in 2017, dengue cases in Rappocini Subdistrict in 2015 occurred in 17 cases, in 2016 there was a significant increase in cases to 36 cases and in 2017 there was a decrease in cases recorded, namely as many as 2 cases from January to October.7 Determination of non-endemic areas based on village/subdistrict stratification that experience cases or deaths due to dengue hemorrhagic fever sequentially, even though the number is only one endemic area.

Deciding the chain of DHF transmission by controlling vectors through the Mosquito Breeding Eradication (PSN) activity is one of the efforts to prevent dengue disease. Behavioral factors are important factors in health problems and in preventing acts. Factors that influence behavior are attitudes, age, values, and factors of trust. Factors that influence actions are knowledge, emotions, perceptions, and others

Mosquito Breeding eradication is one way to prevent dengue disease, wherein the larva free rate $(A B J)$ is one of the factors in the success of the program and its implementation with $3 \mathrm{M}$ Plus activities. The program includes activities to drain water reservoirs, close tightly water reservoirs, bury and get rid of used goods and sustainable environmental management. The measure used to determine the density of Aedes aegypti larvae is in addition to ABJ by measuring House Index (HI), Container Index (CI), and Breteau Index (BI) [2]. In an effort to eradicate mosquito nests, the government needs assistance from all levels of society. Higher community participation through periodic and continuous larval examination and the role of Jumantik (larva monitoring person) is expected to be a driving factor for PSN-DBD. Distribution of dengue fever in terms of time and space is important for developing spatial databases, applying statistics spatial and to link this information with the environment, climatic, entomological and socio-economic factors for a particular area. Geographic Information System (GIS) and high-resolution satellite imagery are useful for collecting data for studies of factors that affect dengue fever and vector distribution in areas where millions of people are at risk of contracting dengue fever. Therefore, this study aims to describe the density of Aedes larvae aegypti based on the action of Eradicating Breeding Mosquito (PSN) in endemic areas of DHF in Rappocini Subdistrict, Makassar City. 


\section{Methods}

The type of research used was an observational survey with a descriptive approach with interviews using questionnaires, interview guides, and through direct observation using observation sheets. The study was conducted on May 26 to June 26, 2018 in the Gunung Sari village in Rappocini Subdistrict. The population in this study were all houses in RW 05, RW 06 and RW 08 which were categorized as endemic areas of DHF. Determination of the sample is done by purposive random sampling method so that a sample of 126 houses is obtained while the coordinate points are determined using the Geographic Position System (GPS). Data that has been collected is then analyzed descriptively and presented in table form and interpreted and carried out mapping using ArcGis Dekstop 3.1 software.

\section{Results}

Gunung Sari Village is an endemic area of DHF which after the division took place consisting of 9 RWs and 53 RTs. The number of samples in Gunung Sari Village consists of 126 houses with 660 containers. The results of the study showed that good action of $65.9 \%$ of Dengue Mosquito nest eradication in Gunung Sari Village as endemic areas (Table 1). Observation results on 660 containers in endemic areas, the most widely used landfill by respondents is buckets $(24.2 \%)$ while the most non-landfill is pots / vases $(22.6 \%)$ and the most widely used natural landfill is puddles water (2.9\%) (Table 4). The presence of Aedes aegypti larvae in DHF endemic areas was obtained in 79 houses (62.7\%) which were positively larvae (Table 2). The presence of larvae in the endemic area of DHF in the most TPA was buckets (31\%) (Table 4).

Table 1. Distribution of respondents based on MBE Behavior in Dengue Endemic area in Gunung Sari Village Rappocini Subdistrict Makassar

\begin{tabular}{|c|c|c|c|c|c|c|c|c|}
\hline \multirow{2}{*}{ Behavior } & \multicolumn{2}{|c|}{ RW 05} & \multicolumn{2}{|c|}{ RW 06} & \multicolumn{2}{|c|}{ RW 08} & \multicolumn{2}{|c|}{ Total } \\
\hline & $\mathbf{N}$ & $\%$ & $\mathbf{n}$ & $\%$ & $\mathbf{n}$ & $\%$ & $\mathbf{N}$ & $\%$ \\
\hline Good & 2 & 71,4 & 20 & 50 & 38 & 74,5 & 83 & 65 , \\
\hline Enough & $\begin{array}{l}5 \\
0^{1}\end{array}$ & 28,6 & 20 & 50 & 13 & 25,5 & 43 & $\begin{array}{l}9 \\
34, \\
1\end{array}$ \\
\hline Total & $5^{3}$ & $\begin{array}{l}\text { 100, } \\
0\end{array}$ & 40 & $\begin{array}{l}\text { 100, } \\
0\end{array}$ & 51 & $\begin{array}{l}\text { 100, } \\
0\end{array}$ & $6^{12}$ & $\begin{array}{l}100 \\
, 0\end{array}$ \\
\hline
\end{tabular}

MNE: Mosquito Breeding Eradication 
Table 2. Distribution of Respondents House based on Aedes aegypti larvae existence in Gunung Sari Subdistrict District Rappocini Makassar

\begin{tabular}{ccccccccc}
\hline Larvae & \multicolumn{2}{c}{ RW 05 } & \multicolumn{2}{c}{ RW 06 } & \multicolumn{2}{c}{ RW 08 } & \multicolumn{2}{c}{ Total } \\
\cline { 2 - 9 } existence & $\mathbf{n}$ & $\mathbf{\%}$ & $\mathbf{N}$ & $\mathbf{\%}$ & $\mathbf{n}$ & $\mathbf{\%}$ & $\mathbf{N}$ & $\mathbf{\%}$ \\
\hline Exist & 21 & 60 & 23 & 57,5 & 35 & 68, & 79 & 62,7 \\
Not Exist & 14 & 40 & 17 & 42,5 & 16 & 6 & 47 & 37,3 \\
& & & & & & 31, & & \\
\hline Total & $\mathbf{3 5}$ & $\mathbf{1 0 0}$ & $\mathbf{4 0}$ & $\mathbf{1 0 0}$ & $\mathbf{5 1}$ & $\mathbf{1 0}$ & $\mathbf{1 2 6}$ & $\mathbf{1 0 0}$, \\
& & $\mathbf{0}$ & & $\mathbf{0}$ & & $\mathbf{0 , 0}$ & & $\mathbf{0}$ \\
\hline
\end{tabular}

The presence of Aedes aegypti larvae is associated with the respondents' PSN actions, which are ranked as four. Most of the respondents were ranked $3(40.5 \%)$, namely the presence of positive Aedes aegypti larvae, but the respondents had good 3M-Plus PSN actions (Table 3). Larval density is measured by Mosquito larva Free Numbers (ABJ), House Index (HI), and Container index (CI). ABJ in Gunung Sari Village (37.3\%) was included in the low category $(<95 \%)$ in all RTs in the three RWs. The density of Aedes aegypti larvae, as measured by the House Index (HI), was $62.7 \%$ in the high $\mathrm{HI}$ category (> 37\%), but there was one RT that had low HI (<37\%) from the three RTs in RW 06.

Table 3. Distribution of Aedes aegypti larvae existence based on PSN Act in Gunung Sari Village Rappocini Subdistrict Makassar

\begin{tabular}{ccccccccc}
\hline \multirow{2}{*}{ Rank } & \multicolumn{2}{c}{ RW 05 } & \multicolumn{2}{c}{ RW 06 } & \multicolumn{2}{c}{ RW 08 } & \multicolumn{2}{c}{ Total } \\
\cline { 2 - 9 } & $\mathbf{N}$ & $\mathbf{\%}$ & $\mathbf{n}$ & $\mathbf{\%}$ & $\mathbf{n}$ & $\mathbf{\%}$ & $\mathbf{N}$ & \% \\
\hline 1 & 10 & 28,6 & 8 & 20 & 14 & 27,5 & 32 & 25,4 \\
2 & 4 & 11,4 & 9 & 22,5 & 2 & 3,9 & 15 & 11,9 \\
3 & 15 & 42,9 & 12 & 30 & 24 & 47,1 & 51 & 40,5 \\
4 & 6 & 17,1 & 11 & 27 & 11 & 21,6 & 28 & 22,2 \\
\hline Total & $\mathbf{3 5}$ & $\mathbf{1 0 0 , 0}$ & $\mathbf{4 0}$ & $\mathbf{1 0 0 , 0}$ & $\mathbf{5 1}$ & $\mathbf{1 0 0 , 0}$ & $\mathbf{1 2 6}$ & $\mathbf{1 0 0 , 0}$ \\
\hline
\end{tabular}

Rank 1: No larvae, good behavior Rank 2: No larvae, enough behavior

Rank 3: larva found, good behavior Rank 4: larva found, enough behavior

The results of direct interviews with Larvae Monitoring Person (Jumantik) in Gunung Sari Village with the initials Ibu "Rhh" and Ibu "Rfn", who claimed to have been being jumantik for four years but had not conducted larva examinations in the past week or three months due to lack of coordination and direct orders from the head of sub-district and health center. The two jumantik claimed to have conducted training provided by the health center and the Health Office in terms of theory, practice, and how to fill in the larvae cards. As long as they become jumantik, there are usually 2-3 houses found positive larvae from 100 houses examined in one $\mathrm{RW}$. The examination is carried out every three months and given directions regarding $3 \mathrm{M}$ (Drain, Close, Bury) and give abate powder. The obstacles faced by the two jumantik companies are that there are still residents who refuse to check the condition of their house containers and refuse to use abate. 
Table 4. Distribution of respondents based on container type in Gunung Sari Subdistrict District Rappocini Makassar

\begin{tabular}{|c|c|c|c|c|c|c|c|c|c|c|c|c|c|c|c|c|}
\hline \multirow{2}{*}{$\begin{array}{c}\text { Contain } \\
\text { er type } \\
\text { Storage }\end{array}$} & \multicolumn{4}{|c|}{ RW 05} & \multicolumn{4}{|c|}{ RW 06} & \multicolumn{4}{|c|}{ RW 08} & \multicolumn{4}{|c|}{ Total } \\
\hline & + & - & $\mathbf{n}$ & $\%$ & + & - & $\mathbf{n}$ & $\%$ & + & - & $\mathbf{n}$ & $\%$ & + & - & $\mathbf{N}$ & $\%$ \\
\hline Water & 15 & 25 & 40 & 22,5 & 1 & 20 & 33 & 14,9 & 22 & 20 & 42 & 16,2 & & & & \\
\hline Tub & & & & & 3 & & & & & & & & 50 & 65 & 115 & 17.4 \\
\hline Barrel & 6 & 11 & 17 & 9,5 & 7 & 13 & 20 & 9 & 13 & 18 & 31 & 11,9 & 26 & 42 & 68 & 10.3 \\
\hline Jar & 2 & 1 & 3 & 1,7 & 1 & 0 & 1 & 0,5 & 2 & 5 & 7 & 2,7 & 5 & 6 & 11 & 1.7 \\
\hline Bucket & 23 & 22 & 45 & 25,3 & 1 & 33 & 52 & 23,4 & 31 & 32 & 63 & 24,2 & & & & \\
\hline & & & & & 9 & & & & & & & & 73 & 87 & 160 & 24.2 \\
\hline Galon & 6 & 28 & 34 & 19,1 & 9 & 13 & 22 & 9,9 & 6 & 22 & 28 & 10,8 & 21 & 63 & 84 & 12.7 \\
\hline $\begin{array}{l}\text { Nonstora } \\
\text { ge }\end{array}$ & & & & & & & & & & & & & & & & \\
\hline $\begin{array}{l}\text { Flower } \\
\text { vase }\end{array}$ & 2 & 26 & 28 & 15,7 & $\begin{array}{l}1 \\
0\end{array}$ & 65 & 75 & 33,8 & 7 & 39 & 46 & 17,7 & 19 & 130 & 149 & 22.6 \\
\hline $\begin{array}{l}\text { Pet } \\
\text { drink }\end{array}$ & 0 & 2 & 2 & 1,1 & 0 & 0 & 0 & 0 & 2 & 4 & 6 & 2,3 & 2 & 6 & 8 & 1.2 \\
\hline Rain & 1 & 2 & 3 & 1,7 & 4 & 2 & 6 & 2,7 & 8 & 5 & 13 & 5 & 13 & 9 & 22 & 3.3 \\
\hline Natural & & & & & & & & & & & & & & & & \\
\hline Puddle & 1 & 1 & 2 & 1,1 & 3 & 3 & 6 & 2,7 & 8 & 3 & 11 & 4,2 & 12 & 7 & 19 & 2.9 \\
\hline Tree & 0 & 1 & 1 & 0,6 & 2 & 0 & 2 & 0,9 & 1 & 3 & 4 & 1,5 & & & & \\
\hline hole & & & & & & & & & & & & & 3 & 4 & 7 & 1.1 \\
\hline Other & 1 & 2 & 3 & 1,7 & 4 & 1 & 5 & 2,3 & 7 & 2 & 9 & 3,5 & 12 & 5 & 17 & 2.6 \\
\hline Total & 57 & 121 & 178 & 100 & 7 & 15 & 22 & 100 & 85 & 17 & 260 & 100 & & & & \\
\hline & & & & & 2 & 0 & 2 & & & 5 & & & 236 & 424 & 660 & 100 \\
\hline
\end{tabular}

$(+)=$ found/positive larva Aedes aegypti (-) = Not found/negative larva aedes aegypti

\section{Discussion}

The results of the recognition of the actions of respondents in Gunung Sari Village are in a good category, with the most common action being to drain water reservoirs. PSN actions that are less or rarely done by respondents in Gunung Sari Village or are maintaining larvae feeding fish and larva sidation by applying abate. This is in line with the research conducted by Rahadian that where 6 respondents $(23.1 \%)$ in endemic areas had good DHF prevention measures. The differences that occur can be caused by several things, one of which is the personal experience of respondents whose family members have experienced DHF

The presence of Aedes aegypti larvae observed in each container using the visual method in Gunung Sari Village was found in many buckets. According to Wiser, the habit of people to always fill water in buckets and bathtubs makes it possible for water to stay for a long time and the habit of people to clean the bathtub when it looks dirty and just throw away the water without brushing the surface of the tub, so it allows the eggs to stay . Aedes aegypti larvae were also found in non-landfill in the form of vases/pots of plants which amounted to 149 fruits $(22.6 \%)$. The presence of Aedes aegypti larvae in plant vases/pots in Gunung Sari Village was found in 16 positive houses of Aedes aegypti larvae. Many people use plant vases/pots placed on the yard/yard, but tend to ignore the stagnant water in the vase/pot of the 
plant because it only focuses on the growth and appearance of the plant without realizing that the place can be a habitat for pre-adult mosquitoes.

The existence of Aedes aegypti larvae is associated with mosquito nest eradication. These actions which are ranked in four where houses and respondents in the endemic area of Gunung Sari Village are the research sample, mostly in rank 3 which means that larvae are found in respondent's houses with good actions regarding DBS PSN while the Aedes larvae density Egypt is associated with DHF DHF actions which are ranked to twelve, most of which are in the $3 \mathrm{C}$ category, which means that larvae are found in the respondent's house with good actions regarding DHF DHF with low Aedes aegypti larvae density, high $\mathrm{HI}$ and high CIs that spread in each RT and RW which is the place of research. In Figures 1, 2, 3, and 4, a mapping distribution was presented. The presence of Aedes aegypti larvae associated with DHF PSN action and the density of Aedes aegypti larvae were associated with DHF actions.

This shows that there are other factors that influence the presence of larvae, such as the condition of the house and the environmental characteristics of the mosquito breeding grounds. The results of the research conducted by Lebang showed a map of the presence of larvae at each different point; the larvae were due to an inadequate physical environment so that the nesting and hiding facilities remained even though they had carried out adaptations and $3 \mathrm{M}$.

This shows that there are other factors that influence the presence of larvae, such as the condition of the house and the environmental characteristics of the mosquito breeding grounds. The results of the research conducted by Lebang showed a map of the presence of larvae at each different point; the larvae were due to an inadequate physical environment so that the nesting and hiding facilities remained even though they had carried out adaptations and $3 \mathrm{M}$.

The density of larvae of Aedes aegypti can be seen by surveying houses randomly selected through larvae surveys. The density of larvae measured in this study is larva free numbers (ABJ), House Index (HI), and Container Index (CI). The Gunung Sari village has an ABJ value of $37.3 \%$ which according to Nadifah et al., ABJ numbers are far below the Healthy Indonesia Indicator 2010. The measure of success in eradicating mosquito fever is dengue hemorrhagic free indicator $(\mathrm{ABJ})$ of at least $95 \%$. If $\mathrm{ABJ}$ is $<95 \%$, this indicates that the area has the potential to transmit dengue hemorrhagic fever. Thus Gunung Sari Village has the potential to transmit dengue hemorrhagic fever.

The housing index (HI) value obtained is Gunung Sari Village at $62.7 \%$, which is based on the Gunung Sari urban village density figure (DF) at scale 8. DF is a comparison between positive larvae houses and all houses that were examined. Flick. This HI can describe the presence of larvae of Aedes aegypti. DF above 5 has a high risk of transmission. 18 According to Sunaryo \& Pramestuti if an area has more than $37 \% \mathrm{HI}$, the area has a high risk of dengue transmission. If $\mathrm{HI}$ is less than $37 \%$, prevention can still be done for the occurrence of dengue virus infection.

Besides $\mathrm{ABJ}$ and $\mathrm{HI}$, also the value of container index (HI) in Gunung Sari Village was $32.4 \%$. This shows that the Gunung Sari Village with $\mathrm{CI} \leq 20 \%$ is in a scale $8 \mathrm{DF}$, which has a high risk of dengue transmission. Wati's research states that CI describes information about the number of positive reservoirs found in larvae. CI is actually not very useful from an epidemiological perspective, because it only reveals the percentage of positive larvae TPA (Aedes aegypti breed) but from the results of this study it can be shown that there are many containers for breeding Aedes aegypti larvae as DHF vectors which result in increasingly high risk against the incidence and transmission of DHF. 
The larval density in this study did not correlate with DHF endemicity stratification in an area which was shown in Gunung Sari Village where there were high DHF cases and classified as endemic areas in the last three years. Other factors that influence the presence of Aedes aegypti larvae, which are the vector of DHF transmission that is still found in the region. The researcher concludes that these factors could be due to a dense residential environment. According to Kumayah, small houses and meetings that seem dense cause less lighting in the house so that the air in the house tends to be damp and dark. This condition supports mosquitoes Aedes aegypti larvae to live and breed well.

Empowering jumantik is one way to reduce the incidence of dengue. Based on the results of interviews with Jumantik in Gunung Sari Village, the two cadres only run PJB every three months, but the agenda is not routine and without side from the Puskesmas. This means that the two jumantik cadres have not carried out the maximum examination, and the participation of the puskesmas is not maximum. Many factors influence the performance of jumantik in Gunung Sari Village, which was obtained during interviews, such as the length of work, ability, motivation, work environment, and compensation. The results of the examination and collection of larva monitoring sheets obtained from the Puskesmas in the Gunung Sari Village area showed that larval monitoring was only conducted once a year. From the results of the calculation of the larva monitoring sheet in 2017 compared to the results of the research that the researchers have done, there is a significant difference in the value of $\mathrm{ABJ}, \mathrm{HI}$, and $\mathrm{CI}$ which is then suspected of occurring a bias.

\section{Conclusion}

This study concluded that the act of Eradicating Mosquito Nests (PSN) in the endemic areas of Rappocini Subdistrict, Makassar City, was mostly in the good category and nonendemic DHF, the majority were in a bad category at $65.9 \%$. The larva free rate $(\mathrm{ABJ})$ is in the low category in endemic areas of $37.3 \%$. The House Index (HI) value is in the high category of $62.7 \%$, and the value of the Container Index (CI) is in the high category of $32.4 \%$. The participation of Jumantik cadres in controlling DHF in endemic areas of Gunung Sari Village, Rappocini Sub-District, Makassar City has not been carried out optimally because it does not routinely run larva checks every three months. The suggestions that can be given to the Makassar City Health Office and Community Health Centre are Movement 1 house 1 jumantik to be applied in Makassar City in suppressing dengue morbidity and mortality rates, coordinating jumantik cadres, villages, and RW heads more intensified so that jumantik cadres are more active in conduct periodic larva monitoring and the community can carry out community activities as an effort to eradicate mosquito nests.

\section{References}

[1] WHO.: Dengue and Severe Dengue [Online article] (2016)

[2] Widiyanto, S: Mengenal 10 Penyakit Mematikan (Yogyakarta: PT Pustaka Insan Madani) (2009)

[3] Dinas Kesehatan Provinsi Sulawesi Selatan.: Profil Kesehatan Sulawesi Selatan Tahun 2012 (Makassar) (2013)

[4] Kementerian Kesehatan RI ,: Demam Berdarah Dengue (DBD) (2017)

[5] Dinas Kesehatan Kota Makassar.: Profil Kesehatan Kota Makassar Tahun 2016 (2017) 